\title{
New Citrus Rootstocks Released by USDA 2001-2010: Field Performance and Nursery Characteristics
}

\author{
Kim D. Bowman ${ }^{1}$ and Lynn Faulkner \\ U.S. Horticultural Research Laboratory, USDA, ARS, 2001 South Rock \\ Road, Ft. Pierce, FL 34945
}

\author{
Mike Kesinger \\ DPI, Florida Department of Agriculture and Consumer Services, Winter \\ Haven, FL 33881
}

Additional index words. orange, grapefruit, mandarin, lemon, lime, huanglongbing, Citrus tristeza virus, phytophthora, diaprepes, disease, cold, cultivar, US-802, US-812, US-897, US-942

\begin{abstract}
Four new citrus rootstocks developed by USDA, ARS and released between 2001 and 2010 have gained considerable commercial popularity in Florida and have been used for propagation of more than 2 million trees over the last 2 years. Results from three new field trials are presented comparing these rootstocks with other important rootstocks, and discussion is presented to summarize field performance in these trials and from numerous other sources. The rootstocks vary widely in their effect on tree vigor. When used as a rootstock for sweet orange, 'US-802' typically supports strong vigor and development of a large tree, 'US-812' and 'US-942' provide moderate vigor, and 'US-897' induces a relatively dwarf tree. Other characteristics and attributes of the four rootstocks are also discussed, including effects on cropping, fruit quality, disease and pest resistance, and tolerance of abiotic factors. Of special relevance, relative tolerance of these rootstocks to huanglongbing (HLB) disease can be surmised from a combination of data from several sources, with 'US-942' and 'US-802' typically providing the best yields per tree in trials containing many rootstocks and affected by HLB. 'US-812' and 'US-897' have appeared to have most utility in locations where HLB is not present or effectively managed, or where trees are being planted at high density to optimize production per unit area. To facilitate continuing expansion of commercial use, information on seed production, and the relative ease of nursery propagation is also presented.
\end{abstract}

Rootstock is widely recognized as an important component of a healthy and productive citrus tree. The rapid spread and devastation of the disease HLB in Florida, believed to be caused by the bacteria Candidatus Liberbacter asiaticus (Las), has come to severely threaten the future of the Florida citrus industry and resulted in major shifts in cultivar use and management practices. Some hybrids of trifoliate orange [Poncirus trifoliata (L.) Raf.] with Citrus sp. have been identified as tolerant to HLB (Albrecht and

Received for publication 24 May 2016. Accepted for publication 18 Aug. 2016.

This research was supported in part by grants from the Florida Citrus Production Research Advisory Council and Florida Citrus Research and Development Foundation.

We would like to thank the many people who have helped with the care of trees and collection of data, including Randy Driggers, Mike Rutherford, Emily Domagtoy, Diane Helseth, Kerry Worton, Sailindra Patel, and Steve Mayo at USDA.

Mention of a trademark, warranty, proprietary product, or vendor does not imply an approval to the exclusion of other products or vendors that also may be suitable.

${ }^{1}$ Corresponding author. E-mail: kim.bowman@ars. usda.gov.
Bowman, 2011, 2012; Bowman et al., 2016; Folimonova et al., 2009), and though first and second generation hybrids of that parentage produce distasteful fruit, selected individual hybrids possess many useful rootstock traits. In consequence, rootstock is now regarded as an even more critical component of successful citrus production in the presence of HLB (Giles and Rusnak, 2015). 'US-802', 'US812', 'US-897', and 'US-942' are hybrid citrus rootstocks released by the U.S. Department of Agriculture (USDA) between 2001 and 2010 (Bowman, 2001, 2007a, 2007b; Bowman and McCollum, 2010), and have become the rootstocks of choice for a substantial percentage of new citrus tree propagations in Florida. Along with high fruit productivity and tree size control, commercial interest in these four USDA rootstocks has been driven by some indication of improved tolerance to HLB in some commercial plantings and field testing.

First commercial use of any of these four rootstocks in Florida began in 2002, when 14,572 nursery trees were propagated on 'US-812' (Kesinger, 2015). In the year of release for 'US-802' and 'US-897' (2007), 21,046 trees were propagated on 'US-802', and 4871 trees on 'US-897'. Following release of 'US-942' in 2010, propagations on all four rootstocks began to increase dramatically (Fig. 1). During the 2014-15 2-year period, 'US-812' was used for propagation of 448,226 trees $(4.9 \%$ of total), 'US- 802 ' was used for 703,796 propagations $(7.7 \%$ of total), 'US-897' was used for 559,092 propagations ( $6.1 \%$ of total), and 'US-942' was used for 333,987 trees (3.6\% of total). Much of the rise in use of the four USDA rootstocks in Florida from 2010 to 2015, corresponded with a notable decline in use of what were the two most common rootstocks, 'Swingle' and 'Carrizo', used for propagations in Florida throughout the previous two decades. In 2007, 'Swingle' and 'Carrizo' were used for $74.5 \%$ of all Florida nursery propagations. During 2015, the four USDA rootstocks combined were used for propagation of $1,033,420$ trees, more propagations than on any other single rootstock, and much more than the 655,587 trees propagated on 'Swingle' and 'Carrizo' rootstocks combined. Using an average planting density of 400 trees per hectare, the four USDA rootstocks would have been used for planting of $\approx 5000$ ha of new citrus in Florida over the last 2 years.

Following release, these four USDA rootstocks have been taken to other citrus production areas of the world, but documentation is scanty regarding level of commercial use. In some cases, this usage was in violation of quarantine or other governmental regulations. It has been reported to the senior author that several hundred hectares of 'Eureka' lemon [Citrus limon (L.) Burm. F] on 'US-897' have been planted in Argentina and Peru with outstanding results. According to data collected by Citrus Research International (Nelspruit, South Africa), 'US-812' rootstock has been used to some extent in South Africa, with $\approx 35,000$ trees propagated on 'US-812' between 2008 and 2015. Based on the excellent performance of these trees, a large number of 'US-812' seed trees have been planted, so commercial use of 'US-812' in South Africa is expected to expand rapidly over the next few years (Johan Jobert, personal communication). Use of these four U.S. rootstocks in China, Brazil, and Mexico has also been reported, but no specific information is available as to quantities propagated or planted in the field.

This report presents new data from three field trials containing all four USDA rootstocks, and will bring together, in discussion, information from multiple other field trials and sources to compare what is known about relative field performance of the four new rootstocks, both with and without HLB. We also present information on nursery characteristics and propagation of the four rootstocks to aid nurserymen and growers in planning for appropriate continued and expanding commercial use.

\section{Materials and Methods}

'US-812' originated from a cross of 'Sunki' mandarin (Citrus reticulata L. Blanco) $\times$ 'Benecke' trifoliate orange ( $P$. trifoliata), 


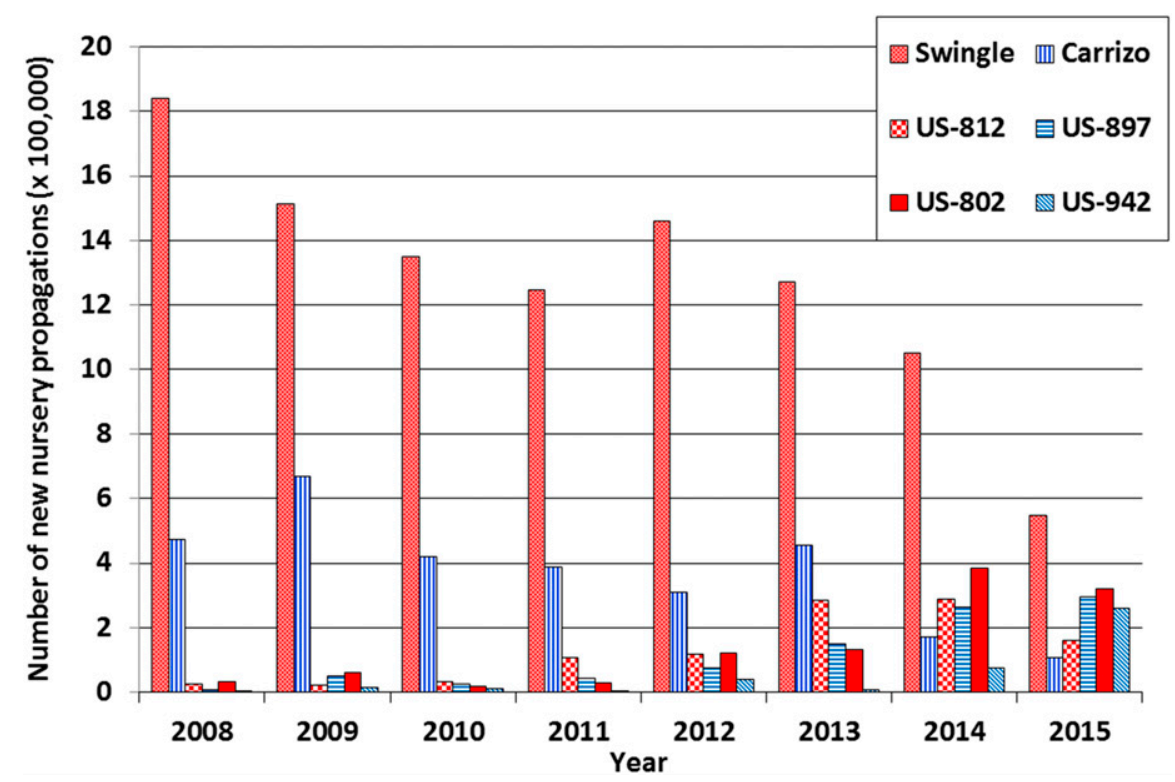

Fig. 1. Comparison of Florida citrus nursery propagations on Swingle, Carrizo, and the four USDA rootstocks, 2008-15.

'US-802' from a cross of 'Siamese' pummelo $(C$. grandis Osbeck) $\times P$. trifoliata, 'US-897' from a cross of 'Cleopatra' mandarin $(C$. reticulata $) \times$ 'Flying Dragon' trifoliate orange ( $P$. trifoliata), and 'US-942' from a cross of 'Sunki' (C. reticulata) $\times$ 'Flying Dragon' (P. trifoliata). The four rootstocks were officially released by USDA as follows: 'US-812' in 2001, 'US-802' in 2007, 'US-897' in 2007, and 'US-942' in 2010. For all four rootstocks, clean budwood was available from Florida Department of Agriculture and Consumer Services, and limited amounts of seed from the Florida Citrus Research Foundation, at the time of release. Other rootstocks used for comparison in the field trials and nursery study were also propagated by seed from certified Florida source trees of the respective cultivars.

Lake county field trial. One trial comparing performance of the four new USDA rootstocks was planted at the Whitmore Foundation Farm in Lake County, FL, in 1997, and contained four replicates of each rootstock planted in a randomized complete block design, and statistical analysis was conducted as randomized complete block design. Trees were propagated by budding disease free 'Hamlin' sweet orange [Citrus sinensis (L.) Osbeck] clone 1-4-1 on true-totype seedlings of the different rootstocks in a greenhouse nursery. The trial was on a soil type classified as Albany sand, and trees were irrigated with under-tree microjets as needed. Tree spacing in the trial was $4.6 \mathrm{~m} \times 7.6 \mathrm{~m}$. Fertilization, weed and disease control were by standard industry methods. Fruit cropping information was collected in December of each year from 2002 to 2007 by individual tree harvest into standard field boxes. No HLB or other significant disease was observed in the block during the years that yield was measured. Tree trunk and canopy size information was collected in 2008 and 2010. Canopy volume was calculated by the formula, volume $=$ (width ${ }^{2} \times$ height) $/ 4$ as described by Wutscher and Hill (1995).

Collier county field trial. A second trial comparing performance of the four new USDA rootstocks was planted on Silver Strand grove in Collier County, FL, in 2002 as a cooperative trial between USDA and Barron Collier Citrus. Trees were propagated by budding disease free 'Valencia' sweet orange $(C$. sinensis) clone 1-14-19 on trueto-type seedlings of the different rootstocks in a greenhouse nursery. This trial contained six replicates of three trees for each rootstock planted in a randomized complete block design, and statistical analysis was conducted as randomized complete block design. The trial was on soil types characterized as Oldsmar and Immokalee, formed into double-row beds, and irrigated with under-tree microjets as needed. Tree spacing in the trial was $3.7 \mathrm{~m}$ $\times 7.3 \mathrm{~m}$. Fertilization, weed and disease control were by standard industry methods. Fruit cropping information was collected in late March or early April of 2010, 2012, 2013 , and 2016 by measuring fruit replicates as they were being harvested into standard fruit pallet boxes. Symptoms of HLB were observed widely in the block during 2010 16. Measurements of canopy size were collected on trees in the trial during Mar. 2016.

St. Lucie county field trial. A third trial comparing performance of the four new USDA rootstocks was planted on the USDA Picos Research Farm in St. Lucie County, FL, in 2003. Trees were propagated by budding disease-free 'Minneola' tangelo scion (Citrus $\times$ paradisi Macf. 'Duncan' $\times C$. reticulata 'Dancy') on true-to-type seedlings of the different rootstocks in a greenhouse nursery. This trial contained four two-tree replicates for each rootstock planted in a randomized complete block design, and statistical analysis was conducted as randomized complete block design. The trial was on soil characterized as Riviera fine sand, formed into doublerow beds, and irrigated with under-tree microjets as needed. Tree spacing in the trial was $3.0 \mathrm{~m} \times 6.0 \mathrm{~m}$. Fertilization, weed and disease control were by standard industry methods. Fruit cropping information was collected in January or February of 2009, 2011, 2013, 2015 , and 2016 by measuring fruit replicates as they were being harvested into standard citrus field boxes. Symptoms of HLB were observed widely in the block beginning in 2007. Trees in the trial were quite vigorous and were hedged and topped several times during the period 2010-16. Trunk crosssectional area (CSA) was collected on trees in the trial at $5 \mathrm{~cm}$ above the graft union during Apr. 2016

Fruit and seed characteristics. Fruit for each rootstock was obtained from seed source trees at the USDA Whitmore Foundation Farm (Lake County, Groveland, FL) in Oct.-Nov. 2015. Four samples of fruit for each rootstock were counted into a 5-L container to determine fruit per volume and calculate fruit per 70-L field box. Seed was extracted from fruit for each of the four samples per rootstock and used to calculate number of seed per fruit. After extraction, seed was treated with a solution of 8-quinolinol sulfate (10 g. $\mathrm{L}^{-1}$; Sigma Chemical Co., St. Louis, MO) and air dried. Four samples of seed for each rootstock were counted into a $100-\mathrm{mL}$ container to determine seed per volume and calculate number of seed per liter. The $100 \mathrm{~mL}$ samples of seeds for each rootstock were weighed and used to calculate individual seed weight.

Seedling characteristics. Four groups of 98 seeds were planted for each rootstock in August using racks of $3.8 \mathrm{~cm} \times 21 \mathrm{~cm}$ cone cells (Cone-tainers; Stuewe and Sons, Tangent, OR) and a soilless potting mix (Pro Mix BX; Premier Horticulture, Inc., Quakertown, PA). Seedlings in cone cells were maintained in a greenhouse at the U.S. Horticultural Research Laboratory, Ft. Pierce, and irrigated as needed, alternating between water and a watersoluble fertilizer mix of $20 \mathrm{~N}-10 \mathrm{P}-20 \mathrm{~K}$ (Peters Professional, The Scotts Company, Marysville, $\mathrm{OH})$ applied with a proportioner at a rate of $400 \mathrm{mg} \cdot \mathrm{L}^{-1} \mathrm{~N}$. No supplemental light was supplied and temperature ranged from 21 to $28^{\circ} \mathrm{C}$. Maximum photosynthetic photon flux in the greenhouse was $1000 \mu \mathrm{mol} \cdot \mathrm{s}^{-1} \cdot \mathrm{m}^{-2}$. After 5 months, each rack was scored for multiple seedlings, vigor, and trueness to type. After scoring, six groups of ten true-to-type seedlings of each rootstock were transplanted to $11-\mathrm{L}$ pots (Treepots; Stuewe and Sons, Inc., Tangent, OR) using Pro Mix BX. Transplanted seedlings were maintained in the greenhouse with alternating water and fertilizer as described above, and stem diameter measured using a caliper $9 \mathrm{~cm}$ above the soil line at 10 months from seed planting.

Budding success. Two experiments were used to evaluate budding performance on the different rootstocks. Budding Expt. 1 made use of the seedlings generated in the seedling characteristics study described above. After 
measuring stem diameter, in July, the six groups of 10 seedlings per rootstock were budded with 'Valencia' sweet orange clone 1-14-19 and managed following conventional Florida nursery practice. Budded plants were maintained in the same greenhouse (without supplemental light) and watered and fertilized as for the seedling study described above. Budded plants were scored for bud survival at 5 weeks, buds growing at 10 weeks, and number of field ready plants at 45 weeks from budding.

Budding Expt. 2 made use of a different group of seedlings for each of the rootstocks. Seeds were planted into individual conetainers in November, and strong true-totype seedlings were selected and transplanted into 4-L plastic pots in June. Potting mix and fertilization for the seeding and transplanted stage were as in the seedling study described above. Three groups of 16-17 seedlings per rootstock were budded with 'Valencia' sweet orange clone 1-14-19 in September and managed following conventional Florida nursery practice. The plants were maintained in a greenhouse at USHRL, and without supplemental light. Budded plants were scored for bud survival at 5 weeks, buds growing at 10 weeks, and shoot length of the growing buds at 10 weeks.

Statistical analysis. Data were analyzed using Statistica 10 software (Dell Statistica, Tulsa, OK) for analysis of variance and other tests, as indicated in the sections describing methods and results for the different experiments.

\section{Results}

Field performance. In the Lake County 'Hamlin' trial, trees on 'US-942' rootstock had the highest cumulative yield per tree and highest annual yield in four of the six harvest seasons (Table 1). The second and third highest yielding rootstocks, 'Carrizo' and 'US-802', were a little more than $100 \mathrm{~kg}$ fruit behind 'US-942' in cumulative yield over the 6-year period, and each was the highest yielding rootstock in one of the six seasons. Cumulative yield of trees on 'US-812' trailed 'US-942' by more than $200 \mathrm{~kg}$ per tree, whereas yield on 'Swingle' and 'US-897' trailed by $\approx 300 \mathrm{~kg}$ per tree. Trees on 'Flying Dragon' rootstock, which were quite small, had a cumulative yield of $268 \mathrm{~kg}$ per tree, which was $\approx 34 \%$ of the yield of trees on 'US942'.

In the 'Hamlin' trial, 'Carrizo' produced trees with the largest canopy height when they were measured in 2008 and also again in 2010, whereas 'Flying Dragon' produced clearly the smallest trees throughout (Table 2). 'US-802' produced a tree that was similar in size to trees on 'Carrizo', whereas the rootstocks 'US-812', 'Swingle', and 'US942' produced trees that were somewhat intermediate in size. Trees on 'US-897' appeared somewhat smaller than trees on the rootstocks of intermediate size, but without statistical significance, whereas trees on 'US-897' were significantly larger than trees on 'Flying Dragon'. Based on canopy volume in 2010, trees on 'US-802' were the largest, with trees on 'US-942 $\approx 81 \%$ that size, trees on 'US-812' $\approx 79 \%$ size, trees on 'US-897' $\approx 61 \%$ size, and trees on 'Flying Dragon' $\approx 33 \%$ size. HLB was first found in the grove containing this trial in Oct. 2010, and is not thought to have had any effect on the yield and tree size information presented here.

In the 'Valencia' Collier County trial, trees on 'US-802' had the highest yield in each of the four harvest seasons, and a significantly higher cumulative yield than all other rootstocks (Table 3). Trees on 'US-942' were second highest in cumulative yield, but not significantly different from 'Cleopatra', 'Carrizo', 'Swingle', 'US-812', or 'Kinkoji'.
Trees on 'US-897' had cumulative yields significantly less than the intermediate group and $\approx 43 \%$ the yield per tree, as compared with trees on 'US-802'. Tree canopy area, as determined at harvest in 2016 was significantly different among the rootstocks, with a fair association between canopy area and cumulative yield for most rootstocks: The largest trees yielded the most fruit. Corresponding to this, yield efficiency ( $\mathrm{kg}$ fruit per $\mathrm{m}^{2}$ ) did not differ significantly between the rootstocks. HLB was observed in this 'Valencia' trial during harvest in 2010, 2012, 2013, and 2016, and is thought to have had a substantial effect on fruit yield during this period.

In the 'Minneola' trial in St. Lucie County, overall yield over multiple years was relatively low. Trees on 'US-897' had the highest cumulative yield ( $93 \mathrm{~kg} / \mathrm{tree})$ and the highest yield in two of the five harvest seasons (Table 4). Trees on 'US-942' were second highest in cumulative yield $(87 \mathrm{~kg} /$ tree), had the highest yield (or tied for highest) in four of the five harvest seasons, and were not significantly different from trees on 'US-897' in cumulative yield. The other eight rootstocks ('US-802', 'Swingle', 'US-812', 'Sour orange', 'Flying Dragon', 'Carrizo', 'Kinkoji', and 'Cleopatra') had a significantly lower cumulative yield than 'US-897' and 'US-942', ranging from 33 to $57 \mathrm{~kg} /$ tree. HLB was observed in this 'Minneola' trial beginning in 2008, and all trees exhibited some leaf symptoms of HLB at each of the harvests studied. Tree size as measured by trunk CSA varied from $38 \mathrm{~cm}^{2}$ for trees on 'Flying Dragon', to $119 \mathrm{~cm}^{2}$ for trees on 'Cleopatra'. The two rootstocks producing the largest trees, 'Cleopatra' and 'Kinkoji', were also the lowest in cumulative fruit yield. The highest yielding rootstock, 'US-897', produced trees that were significantly larger than trees on 'Flying

Table 1. Yield of 'Hamlin' sweet orange trees in a Lake County field trial without huanglongbing.

\begin{tabular}{lccccccc}
\hline Rootstock & $\begin{array}{c}\text { Yield 2002 } \\
(\mathrm{kg} / \text { tree })\end{array}$ & $\begin{array}{c}\text { Yield 2003 } \\
(\mathrm{kg} / \text { tree })\end{array}$ & $\begin{array}{c}\text { Yield 2004 } \\
(\mathrm{kg} / \text { tree })\end{array}$ & $\begin{array}{c}\text { Yield 2005 } \\
(\mathrm{kg} / \text { tree })\end{array}$ & $\begin{array}{c}\text { Yield 2006 } \\
(\mathrm{kg} / \text { tree })\end{array}$ & $\begin{array}{c}\text { Yield 2007 } \\
(\mathrm{kg} / \text { tree })\end{array}$ & $\begin{array}{c}\text { Cumulative yield } \\
(\mathrm{kg} / \mathrm{tree})\end{array}$ \\
\hline US-942 & $110 \mathrm{a}$ & $120 \mathrm{a}$ & $123 \mathrm{ab}$ & $164 \mathrm{a}$ & $123 \mathrm{a}$ & $148 \mathrm{ab}$ \\
Carrizo & $79 \mathrm{ab}$ & $107 \mathrm{ab}$ & $125 \mathrm{a}$ & $159 \mathrm{ab}$ & $84 \mathrm{ab}$ & $125 \mathrm{abc}$ & $788 \mathrm{a}$ \\
US-802 & $66 \mathrm{~b}$ & $95 \mathrm{ab}$ & $107 \mathrm{abc}$ & $136 \mathrm{ab}$ & $100 \mathrm{ab}$ & $166 \mathrm{a}$ \\
US-812 & $89 \mathrm{ab}$ & $66 \mathrm{bc}$ & $76 \mathrm{abc}$ & $136 \mathrm{ab}$ & $77 \mathrm{~b}$ & $120 \mathrm{abc}$ & $670 \mathrm{ab}$ \\
Swingle & $56 \mathrm{bc}$ & $64 \mathrm{bc}$ & $77 \mathrm{abc}$ & $125 \mathrm{ab}$ & $61 \mathrm{bc}$ & $112 \mathrm{abc}$ & $565 \mathrm{~b}$ \\
US-897 & $72 \mathrm{~b}$ & $74 \mathrm{bc}$ & $61 \mathrm{bc}$ & $102 \mathrm{bc}$ & $61 \mathrm{bc}$ & $92 \mathrm{bc}$ \\
Flying Dragon & $23 \mathrm{c}$ & $46 \mathrm{c}$ & $49 \mathrm{c}$ & $64 \mathrm{c}$ & $23 \mathrm{c}$ & $64 \mathrm{c}$ & $463 \mathrm{bc}$ \\
\hline
\end{tabular}

Mean separations for significant analysis of variance within columns were by Duncan's multiple range test at $P<0.05$.

${ }^{\mathrm{z}}$ Cumulative yield is the total yield over six harvest seasons, 2002-07.

Table 2. 'Hamlin' sweet orange tree size in a Lake County field trial without huanglongbing.

\begin{tabular}{|c|c|c|c|c|c|c|}
\hline Rootstock & $\begin{array}{l}2008 \text { Canopy } \\
\text { Ht (m) }\end{array}$ & $\begin{array}{l}2008 \text { scion trunk } \\
\text { CSA }\left(\mathrm{cm}^{2}\right)\end{array}$ & $\begin{array}{l}2008 \text { rootstock trunk } \\
\text { CSA }\left(\mathrm{cm}^{2}\right)\end{array}$ & $\begin{array}{l}2010 \text { canopy } \\
\text { Ht (m) }\end{array}$ & $\begin{array}{l}2010 \text { canopy } \\
\text { width (m) }\end{array}$ & $\begin{array}{l}2010 \text { canopy } \\
\text { volume }\left(\mathrm{m}^{3}\right)\end{array}$ \\
\hline US- 802 & $3.12 \mathrm{a}$ & 158 & $466 \mathrm{a}$ & $3.20 \mathrm{ab}$ & $3.82 \mathrm{a}$ & $11.83 \mathrm{a}$ \\
\hline US-812 & $2.96 \mathrm{ab}$ & 106 & $217 \mathrm{~b}$ & $3.06 \mathrm{~b}$ & $3.47 \mathrm{ab}$ & $9.31 \mathrm{abc}$ \\
\hline US-942 & $2.95 \mathrm{ab}$ & 145 & $277 \mathrm{~b}$ & $3.10 \mathrm{ab}$ & $3.49 \mathrm{ab}$ & $9.55 a b c$ \\
\hline US-897 & $2.74 \mathrm{~b}$ & 83 & $184 \mathrm{~b}$ & $2.92 \mathrm{~b}$ & $3.12 \mathrm{~b}$ & $7.25 \mathrm{c}$ \\
\hline Flying Dragon & $2.02 \mathrm{c}$ & 48 & $217 \mathrm{~b}$ & $2.24 \mathrm{c}$ & $2.62 \mathrm{c}$ & $3.89 \mathrm{~d}$ \\
\hline
\end{tabular}

CSA $=$ cross-sectional area.

Mean separations for significant analysis of variance within columns were by Duncan's multiple range test at $P<0.05$. 
Table 3. Yield, canopy area, and yield efficiency of 'Valencia' sweet orange trees in a Collier County field trial with huanglongbing.

\begin{tabular}{|c|c|c|c|c|c|c|c|}
\hline Rootstock & $\begin{array}{l}\text { Yield } 2010 \\
(\mathrm{~kg} / \text { tree })\end{array}$ & $\begin{array}{c}\text { Yield } 2012 \\
(\mathrm{~kg} / \text { tree })\end{array}$ & $\begin{array}{c}\text { Yield } 2013 \\
(\mathrm{~kg} / \text { tree })\end{array}$ & $\begin{array}{c}\text { Yield } 2016 \\
(\mathrm{~kg} / \text { tree })\end{array}$ & $\begin{array}{c}\text { Cumulative yield } \\
\text { (kg/tree) }\end{array}$ & $\begin{array}{c}\text { Canopy area } \\
\left(\mathrm{m}^{2}\right)\end{array}$ & $\begin{array}{l}\text { Yield efficiency } \\
\left(\mathrm{kg} / \mathrm{m}^{2}\right)\end{array}$ \\
\hline$\overline{\mathrm{US}}-802$ & $83 \mathrm{a}$ & $69 a$ & $101 \mathrm{a}$ & $95 \mathrm{a}$ & $347 \mathrm{a}$ & $7.5 \mathrm{a}$ & 46.5 \\
\hline US-942 & $59 \mathrm{bc}$ & $69 \mathrm{a}$ & $82 \mathrm{ab}$ & $80 \mathrm{ab}$ & $290 \mathrm{~b}$ & $6.0 \mathrm{bc}$ & 48.7 \\
\hline Cleopatra & $59 \mathrm{bc}$ & $56 \mathrm{ab}$ & $83 \mathrm{ab}$ & $75 \mathrm{~b}$ & $273 \mathrm{~b}$ & $6.6 \mathrm{ab}$ & 41.2 \\
\hline Carrizo & $49 \mathrm{bc}$ & $52 \mathrm{ab}$ & $77 \mathrm{ab}$ & $70 \mathrm{~b}$ & $250 \mathrm{~b}$ & $5.4 \mathrm{~cd}$ & 46.8 \\
\hline Swingle & $58 \mathrm{bc}$ & $56 \mathrm{ab}$ & $63 \mathrm{bc}$ & $66 \mathrm{~b}$ & $243 \mathrm{~b}$ & $5.9 \mathrm{bcd}$ & 41.3 \\
\hline US-812 & $65 \mathrm{~b}$ & $42 \mathrm{bc}$ & $66 \mathrm{bc}$ & $65 \mathrm{~b}$ & $238 \mathrm{~b}$ & $5.3 \mathrm{~cd}$ & 45.8 \\
\hline Kinkoji & $60 \mathrm{bc}$ & $43 \mathrm{bc}$ & $65 \mathrm{bc}$ & $69 \mathrm{~b}$ & $236 \mathrm{~b}$ & $4.9 \mathrm{~d}$ & 48.2 \\
\hline US-897 & $42 \mathrm{c}$ & $25 \mathrm{c}$ & $51 \mathrm{c}$ & $32 \mathrm{c}$ & $150 \mathrm{c}$ & $3.9 \mathrm{e}$ & 38.9 \\
\hline
\end{tabular}

Mean separations for significant analysis of variance within columns were by Duncan's multiple range test at $P<0.05$.

${ }^{z}$ Cumulative yield is the total yield over four harvest seasons: 2010, 2012, 2013, and 2016.

${ }^{\mathrm{y}}$ Canopy area measured in 2016.

${ }^{\mathrm{x}}$ Yield efficiency was calculated as cumulative yield divided by canopy area.

Table 4. Yield, trunk cross-sectional area (CSA), and yield efficiency of 'Minneola' tangelo trees in a St. Lucie County field trial with huanglongbing.

\begin{tabular}{|c|c|c|c|c|c|c|c|c|}
\hline Rootstock & $\begin{array}{c}\text { Yield } 2009 \\
(\mathrm{~kg} / \text { tree })\end{array}$ & $\begin{array}{c}\text { Yield } 2011 \\
(\mathrm{~kg} / \text { tree })\end{array}$ & $\begin{array}{c}\text { Yield } 2013 \\
(\mathrm{~kg} / \text { tree })\end{array}$ & $\begin{array}{c}\text { Yield } 2015 \\
(\mathrm{~kg} / \text { tree })\end{array}$ & $\begin{array}{c}\text { Yield } 2016 \\
(\mathrm{~kg} / \text { tree })\end{array}$ & $\begin{array}{c}\text { Cumulative yield } \\
(\mathrm{kg} / \text { tree })\end{array}$ & $\begin{array}{l}\text { Trunk CSA } \\
\left(\mathrm{cm}^{2}\right)\end{array}$ & $\begin{array}{l}\text { Yield efficiency } \\
\left(\mathrm{kg} / \mathrm{cm}^{2}\right)\end{array}$ \\
\hline$\overline{\mathrm{US}}-897$ & $8 \mathrm{ab}$ & 6 & $18 \mathrm{~b}$ & $45 \mathrm{a}$ & 17 & $93 \mathrm{a}$ & $71 \mathrm{bc}$ & $1.3 \mathrm{a}$ \\
\hline US-942 & $9 \mathrm{a}$ & 8 & $27 \mathrm{a}$ & $26 \mathrm{ab}$ & 17 & $87 \mathrm{a}$ & $76 \mathrm{bc}$ & $1.2 \mathrm{a}$ \\
\hline Swingle & $6 \mathrm{a}-\mathrm{d}$ & 5 & $15 \mathrm{~b}-\mathrm{d}$ & $23 \mathrm{~b}$ & 8 & $57 \mathrm{~b}$ & $71 \mathrm{bc}$ & $0.8 \mathrm{~b}$ \\
\hline US-802 & $2 \mathrm{e}$ & 2 & $17 \mathrm{bc}$ & $20 \mathrm{~b}$ & 10 & $51 \mathrm{~b}$ & $96 \mathrm{ab}$ & $0.6 \mathrm{~b}-\mathrm{d}$ \\
\hline Sour orange & $7 \mathrm{a}-\mathrm{c}$ & 6 & $12 b-d$ & $18 \mathrm{~b}$ & 7 & $49 \mathrm{~b}$ & $85 \mathrm{bc}$ & $0.6 \mathrm{~b}-\mathrm{d}$ \\
\hline US-812 & $3 \mathrm{de}$ & 4 & $12 \mathrm{~b}-\mathrm{d}$ & $17 \mathrm{~b}$ & 13 & $49 \mathrm{~b}$ & $61 \mathrm{~cd}$ & $0.7 \mathrm{~b}$ \\
\hline Flying Dragon & $5 \mathrm{~b}-\mathrm{e}$ & 6 & $9 \mathrm{~cd}$ & $14 \mathrm{~b}$ & 9 & $44 \mathrm{~b}$ & $38 \mathrm{~d}$ & $1.1 \mathrm{a}$ \\
\hline Carrizo & $4 \mathrm{c}-\mathrm{e}$ & 4 & $11 \mathrm{~b}-\mathrm{d}$ & $14 \mathrm{~b}$ & 6 & $39 \mathrm{~b}$ & $58 \mathrm{~cd}$ & $0.6 \mathrm{bc}$ \\
\hline Kinkoji & $5 \mathrm{~b}-\mathrm{e}$ & 3 & $10 \mathrm{~cd}$ & $11 \mathrm{~b}$ & 10 & $38 \mathrm{~b}$ & $115 \mathrm{a}$ & $0.3 \mathrm{~cd}$ \\
\hline Cleopatra & $3 \mathrm{c}-\mathrm{e}$ & 4 & $8 \mathrm{~d}$ & $4 \mathrm{~b}$ & 13 & $33 \mathrm{~b}$ & $119 \mathrm{a}$ & $0.3 \mathrm{~d}$ \\
\hline
\end{tabular}

Mean separations for significant analysis of variance within columns were by Duncan's multiple range test at $P<0.05$.

${ }^{z}$ Cumulative yield is the total yield over five harvest seasons: 2009, 2011, 2013, 2015, and 2016.

${ }^{y}$ Yield efficiency was calculated as cumulative yield divided by trunk CSA.

Dragon', and significantly smaller than trees on 'Kinkoji' and 'Cleopatra'. A ratio of cumulative yield to trunk CSA can be used to estimate the efficiency of fruit production per tree size on a particular rootstock. In this trial, ratio of yield to CSA was significantly higher for trees on 'US-897', 'US-942', and 'Flying Dragon' (ranging from 1.3 to 1.1 $\mathrm{kg} \cdot \mathrm{cm}^{-2}$ ) than for trees on all the other rootstocks. Corresponding to their low yields and large CSAs, 'Cleopatra' and 'Kinkoji' had the lowest yield to CSA ratios $(0.3$ $\left.\mathrm{kg} \cdot \mathrm{cm}^{-2}\right)$.

Fruit and seed characteristics. Fruit size of seed fruit for the different rootstocks differed greatly, with 'Cleopatra' and 'US942 ' having the smallest fruit, and 'US-802' having the largest fruit (Table 5). The seediness of fruit also differed significantly between rootstocks, with 'US-802' and 'Sour orange' having 39-40 seed per fruit, whereas 'US-942', 'US-897', 'US-812', and 'Cleopatra' had 9-13 seed per fruit. The amount of seed obtained per field box of fruit will differ quite dramatically by rootstock. More than 15,000 seed per field box can be expected from 'Cleopatra', while the amount of seed obtained from one field box of 'US-802' fruit will typically be $\approx 5000$. Seed weight and seed volume were somewhat associated with fruit size, with 'US-802' having the largest fruit and heaviest seed $(236 \mathrm{mg})$ and 'Cleopatra' having the smallest fruit and lightest seed (99 mg).

Seedling characteristics. Seed of all the rootstocks was polyembryonic and often produced multiple seedlings from a single seed (Table 5). The number of seeds yielding more than one seedling ranged from $18 \%$ for 'Sour orange', to $66 \%$ for 'US-942'. Genetic uniformity from seed (because of nucellar polyembryony) has traditionally been an important characteristic in breeding and selecting citrus rootstocks. For all the rootstocks examined here, the polyembryonic seed produced a large proportion of true-totype seedlings of nucellar origin, but this varied somewhat by rootstock, as did seedling vigor. The assessment of "strong true-totype seedlings" takes into account both characteristics, and ranged from $57 \%$ for 'US-812', to $75 \%$ for 'US-942'. Seedling stem diameter provides a measure of relative growth of a group of selected strong true-totype seedlings for the different rootstocks under good greenhouse conditions. 'Swingle' rootstock produced the largest seedlings $(11.8 \mathrm{~mm})$ at 10 months from seed, whereas 'US-812' and 'US-897' produced the smallest $(6.7 \mathrm{~mm})$.

Budding success. The success of budding scions to the different rootstocks was compared in two different experiments, budded in different months, but both using 'Valencia' sweet orange clone 1-14-19 scion (Table 6). In Expt. 1, budded in July, bud survival at 5 weeks varied from $77 \%$ for 'Sour orange', to $98 \%$ for 'US-812', but variability was high and there were no significant differences among the rootstocks. In Expt. 2, bud survival was best on 'US-812', 'Sour orange', and 'Cleopatra' $(100 \%)$, and was significantly higher than on 'US-897' (94\%), 'Swingle' (90\%), and 'US-942' (88\%). Measures of budbreak at 10 weeks provided nearly identical relative ranking of the different rootstocks in both experiments, with 'US-802' and 'Swingle' consistently exhibiting significantly lower budbreak than the other five rootstocks. Plants budded on 'Cleopatra' had significantly longer shoots than the other rootstocks at 10 weeks, with an average shoot length of $322 \mathrm{~mm}$, whereas shoot length on 'Swingle' was significantly shorter than the other rootstocks, at $107 \mathrm{~mm}$. The proportion of budded trees that were suitable for field planting at 45 weeks after budding was $95 \%$ to $100 \%$ for 'US-812', 'Cleopatra', 'Sour orange', 'US-942', and 'US-897', while this proportion was significantly lower for 'US-802' and 'Swingle', at 56\% and 57\%, respectively. Not surprisingly, there appeared to be an association between the success of early budbreak on a rootstock, early shoot length of the growing bud, and the proportion of field trees that were suitable for field planting after 45 weeks.

\section{Discussion}

Assessment of nursery related traits for 'US-802', 'US-812', 'US-897', and 'US-942' in this study indicates similarity to other commonly used rootstocks for most important characteristics. Seedling uniformity, vigor, and budding success varied among the rootstocks, but should be manageable for successful nursery production. Grow-out from budding was significantly weaker for 'Valencia' on 'US-802' than for most of the other rootstocks, but was similar to or better than that found for 'Swingle' (Table 6). Florida nurseries have developed special techniques for dealing with the recalcitrant 
Table 5. Fruit, seed, and seedling characteristics for rootstock cultivars.

\begin{tabular}{|c|c|c|c|c|c|c|c|}
\hline Rootstock & $\begin{array}{l}\text { Fruit per } \\
\text { field box }\end{array}$ & $\begin{array}{l}\text { Seeds per } \\
\text { fruit }\end{array}$ & $\begin{array}{l}\text { Seed wt } \\
(\mathrm{mg})\end{array}$ & $\begin{array}{r}\text { Stored } \\
\text { seeds } / \mathrm{L}\end{array}$ & $\begin{array}{c}\text { Multiple } \\
\text { seedlings (\%) }\end{array}$ & $\begin{array}{l}\text { Strong true-to-type } \\
\text { seedlings }(\%)\end{array}$ & $\begin{array}{l}\text { Stem diam at } \\
10 \mathrm{mo} .(\mathrm{mm})\end{array}$ \\
\hline$\overline{\text { US-942 }}$ & $1,295 \mathrm{a}$ & $9.2 \mathrm{c}$ & $130 \mathrm{~d}$ & $4,200 \mathrm{~b}$ & $66 \mathrm{a}$ & $75 \mathrm{a}$ & $9.0 \mathrm{c}$ \\
\hline US-802 & $126 \mathrm{e}$ & $40.4 \mathrm{a}$ & $236 \mathrm{a}$ & $2,182 \mathrm{e}$ & $39 \mathrm{c}$ & $73 \mathrm{a}$ & $11.4 \mathrm{~b}$ \\
\hline US-812 & $630 \mathrm{c}$ & $12.1 \mathrm{c}$ & $181 \mathrm{bc}$ & $3,142 \mathrm{c}$ & $50 \mathrm{~b}$ & $57 \mathrm{~b}$ & $6.7 \mathrm{e}$ \\
\hline US-897 & $899 \mathrm{~b}$ & $13.3 \mathrm{c}$ & $123 \mathrm{~d}$ & $4,510 \mathrm{~b}$ & $44 \mathrm{bc}$ & $66 \mathrm{ab}$ & $6.7 \mathrm{e}$ \\
\hline Swingle & $220 \mathrm{~d}$ & $18.1 \mathrm{~b}$ & $196 \mathrm{~b}$ & $2,630 \mathrm{~d}$ & $22 \mathrm{~d}$ & $64 \mathrm{ab}$ & $11.8 \mathrm{a}$ \\
\hline Cleopatra & $1,295 \mathrm{a}$ & $11.7 \mathrm{c}$ & $99 \mathrm{e}$ & $5,003 \mathrm{a}$ & $42 \mathrm{bc}$ & $73 \mathrm{a}$ & $7.5 \mathrm{~d}$ \\
\hline Sour orange & $231 \mathrm{~d}$ & $39.1 \mathrm{a}$ & $173 \mathrm{c}$ & $2,207 \mathrm{e}$ & $18 \mathrm{~d}$ & $59 \mathrm{~b}$ & $7.8 \mathrm{~d}$ \\
\hline
\end{tabular}

Mean separations for significant analysis of variance within columns were by Duncan's multiple range test at $P<0.05$.

Table 6. Budding success of 'Valencia' sweet orange scion on rootstock cultivars.

\begin{tabular}{|c|c|c|c|c|c|c|}
\hline \multirow[b]{2}{*}{ Rootstock } & \multicolumn{2}{|c|}{ Bud survival at 5 weeks $(\%)$} & \multicolumn{2}{|c|}{ Bud break at 10 weeks $(\%)$} & \multirow{2}{*}{$\begin{array}{l}\text { Shoot length at } \\
10 \text { weeks }^{\mathrm{y}}(\mathrm{mm})\end{array}$} & \multirow{2}{*}{$\begin{array}{c}\text { Field ready trees at } \\
45 \text { weeks }^{\mathrm{z}}(\%)\end{array}$} \\
\hline & Expt. $1^{z}$ & Expt. $2^{y}$ & Expt. $1^{z}$ & Expt. $2^{y}$ & & \\
\hline US-942 & 90 & $88 \mathrm{c}$ & $91 \mathrm{a}$ & $100 \mathrm{a}$ & $182 \mathrm{c}$ & $98 \mathrm{a}$ \\
\hline US-897 & 87 & $94 \mathrm{~b}$ & $95 \mathrm{a}$ & $100 \mathrm{a}$ & $194 \mathrm{c}$ & $95 \mathrm{a}$ \\
\hline US-812 & 98 & $100 \mathrm{a}$ & $98 \mathrm{a}$ & $96 \mathrm{a}$ & $198 \mathrm{c}$ & $100 \mathrm{a}$ \\
\hline US-802 & 94 & $98 \mathrm{a}$ & $56 \mathrm{~b}$ & $80 \mathrm{~b}$ & $181 \mathrm{c}$ & $56 \mathrm{~b}$ \\
\hline Swingle & 87 & $90 \mathrm{c}$ & $31 \mathrm{c}$ & $71 \mathrm{c}$ & $107 \mathrm{~d}$ & $57 \mathrm{~b}$ \\
\hline Sour orange & 77 & $100 \mathrm{a}$ & $96 \mathrm{a}$ & $94 \mathrm{a}$ & $247 \mathrm{~b}$ & $98 \mathrm{a}$ \\
\hline Cleopatra & 95 & $100 \mathrm{a}$ & $100 \mathrm{a}$ & $100 \mathrm{a}$ & $322 \mathrm{a}$ & $100 \mathrm{a}$ \\
\hline
\end{tabular}

Mean separations for significant analysis of variance within columns were by Duncan's multiple range test at $P<0.05$.

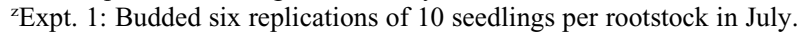

${ }^{y}$ Expt. 2: Budded three replications of 16-17 seedlings per rootstock in September.

growth of trees budded on 'Swingle' in the nursery, and these methods should also work with 'US-802'. The information presented here on seed fruit volume, seediness, and seed volume should be helpful for nurseries in Florida and elsewhere to plan for large scale seed production. No attempt has been made to present information on relative growth of seed trees for the four USDA rootstocks, or relative fruitfulness of those seed trees. However, it has been a general observation by the senior author that seed trees of 'US-802' are relatively less vigorous than the other three (contrary to the effect of 'US-802' to induce vigor on a scion grafted to it in the field), whereas seed trees of 'US-942' are relatively less productive of fruit than the other three (contrary to the effect of 'US-942' to induce high productivity on a scion grafted to it).

Since release, propagation of the four USDA rootstocks has been significantly limited by seed availability for propagation. Florida Department of Agriculture records suggest that this limitation has now been addressed through the establishment of much larger numbers of seed trees. By 2015, those records indicate 148 seed trees for 'US-812', 278 seed trees for 'US-942', 402 seed trees for 'US-802', and 606 seed trees for 'US897' (Kesinger, 2015). In addition, in vitro micropropagation of these four rootstocks is possible (Bowman et al., 1997) and has been initiated at commercial scale by at least three Florida companies (Phillip Rucks Citrus Nursery, Frostproof, FL; Agromillora Florida, Inc., Wildwood, FL; Agri-Starts Inc., Apopka, FL). The increased number of seed source trees, combined with micropropagation, should eliminate the availability of rootstock liners as a limiting factor in propagation of 'US-802', 'US-812', 'US-897', and 'US-942' in Florida. The availability of clean budwood and seed in Florida could make these rootstocks available to other parts of the world, although phytosanitary and quarantine restrictions still prevent or limit movement to many other areas.

Documentation of field performance for each of the four USDA rootstocks were provided with the official release (Bowman, 2001, 2007a, 2007b; Bowman and McCollum, 2010), and in numerous publications by the USDA citrus rootstock breeding team individually or in collaborative efforts (Bowman, 1998; Bowman and McCollum, 2015; Bowman et al., 2003, 2016; Bowman and Rouse, 2006; Castle et al., 2004, 2011, 2015a; McCollum et al., 2002; Ritenour et al., 2004; Wutscher and Bowman, 1999; Wutscher and Hill, 1995). Most of those reports were based on performance without the impact of HLB. Some information has also been published on performance of 'US-812' in Puerto Rico (Bowman and Roman, 1999), and performance of 'US-802', 'US-812', and 'US$897^{\prime}$ in Brazil (Blumer and Pompeu, 2005; Pompeu et al., 2002; Pompeu and Blumer, 2014).

For 'US-812', effect of the rootstock on fruit yield, fruit quality, and tree health was outstanding in trials unaffected by HLB, when grafted with 'Valencia' sweet orange (Bowman and Rouse, 2006; Wutscher and Bowman, 1999), 'Hamlin' sweet orange, 'Sunburst' mandarin, 'Fallglo' mandarin, 'Flame' grapefruit (Bowman and Rouse, 2006), and 'Chironja' (Bowman and Roman, 1999). In other trials with 'Hamlin' sweet orange (Table 1), 'Dancy' mandarin and 'Ambersweet' (Bowman and Roman, 1999), and 'Marsh' grapefruit (Castle et al., 2011) yield of trees on 'US-812' were good, but not superior to 'Carrizo' or 'Swingle' rootstocks. The size of trees (tree height, trunk diameter, canopy area, and canopy volume) on 'US812 ' varied by trial, but was typically smaller than trees on 'Carrizo', and similar in size to trees on 'Swingle'.
'US-802' and 'US-897' were released together in 2007, and presented a large contrast in effects on tree vigor in field trials unaffected by HLB. The size of trees on these two rootstocks vary by trial, but typically trees on 'US-802' are very vigorous and larger (tree height, trunk diameter, canopy area, and canopy volume) than trees on 'Carrizo', 'Swingle', or 'US-812', while trees on 'US-897' are smaller than trees on those rootstocks. In one trial with 'Hamlin' scion at 7 years of age, trees on 'US-802' were $4 \mathrm{~m}$ in height and significantly larger than trees on 'Swingle', whereas trees on 'US-897' were $2.4 \mathrm{~m}$ in height and significantly smaller than trees on 'Swingle' (Wutscher and Hill, 1995). In that trial, the size differences between trees on 'US-802' and 'US- 897 ' became even more pronounced in subsequent years. At 18 years of age, height of trees on 'US-802' and 'US-897' were 6.1 and $2.7 \mathrm{~m}$, respectively (Bowman, 2007a, 2007b). Corresponding to this dramatic difference in size, trees on 'US-802' in field trials are usually more productive per tree than those on 'US-897'. In the 'Hamlin' trial described above (Wutscher and Hill, 1995) trees on 'US-802' had a significantly higher cumulative yield $(781 \mathrm{~kg} /$ tree $)$ than trees on 'Swingle' (594 kg/tree), whereas trees on 'US-897' had a significantly lower yield $(462 \mathrm{~kg} /$ tree) through the first four harvest seasons. This large difference in fruit productivity by rootstock continued in subsequent years (Bowman et al., 1997). Despite this large advantage to 'US-802' in productivity per tree, calculations of fruit yield efficiency suggest that 'US-897' is more productive per canopy area or canopy volume in some trials. Based on these differences, growers have typically used 'US-897' for planting at high tree densities, and 'US-802' for planting at low tree densities. Previously published results (Wutscher and Hill, 1995) 
indicated that percent fruit total soluble solids was significantly higher for 'Hamlin' trees on 'US-897' than 'US-802', and this effect on fruit brix has also been observed in other trials. A second trial with 'Hamlin' sweet orange scion unaffected by HLB (Tables 1 and 2) produced similar differences in yield and size for trees on 'US-802' and 'US-897'. This second 'Hamlin' trial confirmed the dwarfing effect of 'US-897' on scions, but demonstrated that trees on 'US-897' were significantly larger than trees on 'Flying Dragon' (another known dwarfing rootstock), at least under Lake County Florida conditions. The relative effects of 'US-802' and 'US-897' on fruit productivity, fruit brix, and tree size were confirmed in a trial with 'Marsh' grapefruit (Castle et al., 2011).

'US-942' is the last of the quartet, released in 2010 , but certainly not the least in performance. In field trials unaffected by HLB, performance of 'US-942' has typically been among the best rootstocks. In a trial with 'Valencia' scion (Wutscher and Bowman, 1999), cumulative yield of 'US-942' was not significantly different from the two highest yielding rootstocks in the trial, 'US-812' and 'Vangasay' lemon, and 'US-942' was significantly more productive than trees on all the other 18 rootstocks, including 'Carrizo', 'Swingle', and 'Sour orange'. Fruit quality on 'US-942' was good in this 'Valencia' trial, with percent total soluble solids among the five highest rootstocks in the trial. In a trial with 'Fallglo' mandarin and 10 rootstocks (including 'Swingle', 'Carrizo', 'Cleopatra', and 'US-812'), cumulative yield was highest for trees on 'US-942' (Bowman, 1998). Fruit yield of trees on 'US-942' was good in trials with 'Ambersweet' and 'Sunburst' mandarin, but not significantly different from trees on 'Carrizo', 'US-812', 'Swingle', and 'Cleopatra' (Bowman and Roman, 1999). 'US-942' was the most productive rootstock in a Lake County 'Hamlin' sweet orange trial unaffected by HLB (Table 1) through 10 years of age, producing significantly more fruit than trees on 'Swingle' or 'US-812'. The size of trees (tree height, trunk diameter, and/or canopy volume) on 'US-942' unaffected by HLB varied by trial, but was typically smaller than trees on 'Carrizo' and 'US-812', and larger than trees on 'US-897' (Table 2) (Bowman, 1998; Wutscher and Bowman, 1999).

The ability for a rootstock to support good tree health and good fruit production under conditions affected by biotic and abiotic hazards is often an important component of rootstock success. Rootstock ratings for some of the most important biotic and abiotic threats to citrus are presented in the third edition of the Florida Citrus Rootstock Selection Guide (Castle et al., 2015a). Those threats for which there is some specific information from field trials available for the four USDA rootstocks, include Citrus tristeza virus (CTV), Phytophthora-Diaprepes Complex (PDC), cold, high $\mathrm{pH}$, and HLB, as summarized below.

The rootstocks 'US-812' and 'US-942' were tested in a field trial infected with a decline strain of CTV from an early age, as can be confirmed by the severe stunting of all trees in the trial on 'Sour orange' rootstock (Wutscher and Bowman, 1999). Although some negative effects from CTV on 'US812' and 'US-942' in that trial cannot be ruled out, it is clear from their outstanding performance in that trial that they are highly tolerant to the Florida decline isolate of CTV, to which 'Sour orange' is highly sensitive. At other field trial sites, these two rootstocks, as well as 'US-802' and 'US-897', were exposed to CTV, but no meaningful comparisons could be made to verify CTV tolerance. Based on parentage and lack of sites where trees performed poorly from unknown causes, it is believed that all four rootstocks are tolerant to common Florida isolates of CTV, including those that cause decline on 'Sour orange' rootstock (Bowman and Garnsey, 2001).

All four USDA rootstocks were tested in a replicated field trial with 'Flame' grapefruit scion in Indian River County Florida severely affected by PDC (Bowman et al., 2003). Trees on the rootstocks 'Swingle' and 'Carrizo' in this trial were severely stunted in growth and in very poor health, while trees on 'US-802', 'US-897', and 'US-942' grew much better and remained in good health, similar to what was found for 'Cleopatra' rootstock in this trial. Performance of 'US812 ' was significantly better in this trial than 'Swingle' and 'Carrizo', but 'US-812' appeared less tolerant of PDC than 'US802', 'US-897', and 'US-942'.

'US-802' and 'US-897' were tested in a 'Hamlin' field trial exposed to significant freeze damage in Dec. 1989, when the trees were $\approx 3$ years old (Wutscher and Hill, 1995). Assessment of damage in that trial following the freeze indicated that trees on 'US-802' were among the least damaged by the freeze and less damaged than trees on 'Swingle', whereas trees on 'US-897' were observed to have more damage than trees on 'Swingle' (Bowman, 2007a, 2007b). These two rootstocks, as well as 'US-812' and 'US-942', were not planted in other field trials that were exposed to major freeze damage suitable for reliable evaluation of cold tolerance.

In two short-term field trials with 'Tahiti' lime (C. latifolia Tan.) on high $\mathrm{pH}$ sites in south Florida, ended prematurely because of Citrus canker (Xanthomonas axonopodis pv. Citri) infection in the scion, results suggested excellent tolerance of high $\mathrm{pH}$ soil along with good fruit yield for that scion with 'US-812' and 'US-897' rootstocks. There was also preliminary indication of excellent tolerance of high $\mathrm{pH}$ soil for 'US-802' and 'US-942' (Castle et al., 2004). Other anecdotal information has supported the observation of good tolerance of high $\mathrm{pH}$ soil for these four rootstocks.

In addition to these specific biotic and abiotic causes, some tree mortality or reduced performance in field trials cannot be clearly placed as to cause. In some trials before HLB in Florida, much of the observed tree decline and death was judged to be caused by citrus blight (Wutscher and Bowman, 1999; Wutscher and Hill, 1995), a citrus tree decline of highly disputed cause (Derrick and Timmer, 2000; Wutscher et al., 1977). In field trials before the advent of HLB in Florida, tree decline or mortality through 8 years of age was normally $0 \%$ to $4 \%$ on the four USDA rootstocks. Since some trees die in trials unaffected by HLB, it may be expected that some instances of tree decline or death is from other causes even with the presence of HLB. However, when Las is present, the effects of HLB appear to dominate in importance. A recent comparison of rootstock trials with and without HLB, suggests that by 7 years of age, widespread Las infection results in an overall $15 \%$ severe tree decline or death, $21 \%$ reduction in tree size, and 33\% reduction in fruit yield (Bowman et al., 2016) as compared with trials unaffected by HLB.

Not surprisingly, current selection of rootstocks for new trees to be planted in Florida hinges strongly on expected tree tolerance to HLB. A preliminary report comparing rootstock performance during the first few years after HLB was discovered in Florida (Albrecht et al., 2012) indicated some differences between rootstocks, but was not conclusive. A recent discussion of the evaluation and interpretation of results of field trials affected by HLB presents some of the issues involved (Castle et al., 2015b). Although considerable variability has been observed between trials (and commercial plantings) containing different rootstocks, additional results from field trials in different locations can be used to assess overall trends of rootstock performance with HLB. Results from the Collier County field trial on a flatwoods site and strongly affected by HLB (Table 3), indicate that 'US-802' was the highest yielding rootstock, followed by 'US942'. In that trial, trees on 'US-802' yielded significantly more fruit than trees on 'Cleopatra', 'Carrizo', 'Swingle', 'US-812', 'Kinkoji', and 'US-897'. Recently published results from a second trial conducted in Polk County on a ridge site, and severely affected by HLB (Bowman et al., 2016), show that trees on 'US-942' yielded the most fruit, the fruit was of good quality, and tree health was among the best. In that trial, trees on 'US-942' yielded significantly more fruit than trees on 'US-802', 'Carrizo', 'Kuharske', 'US812', 'Cleopatra', 'US-897', and 'Kinkoji'. Results from a trial with 'Minneola' scion on a flatwoods site and strongly affected by HLB (Table 4), indicates that 'US-897' provided the best cumulative yield under these conditions, followed by closely by 'US-942'. A comparison of results from the three trials strongly affected by HLB suggests that 'US942' is the most consistent in good fruit productivity per tree across both ridge and flatwoods sites, while 'US-802' was the top performer at one flatwoods site and 'US-897' at the other. It is not clear how the different scions in the two flatwoods trials reported here influenced the different relative performance of the rootstocks. However, trees in the Collier County 'Valencia' trial 
remained well spaced throughout the trial, while trees in the 'Minneola' trial became quite crowded during the course of the test and were hedged and topped to control size. It is likely that some of the outstanding performance for 'US-897' in the 'Minneola' trial is due to its better adaptation to those relatively high density conditions. 'US-897' relative performance will appear much better across all three trials, if one assumes trees on this rootstock would be planted at a higher tree density to compensate for the smaller tree size. Although combined results from these three trials severely affected by HLB are not conclusive, the superior performance of 'US942 ' in all three suggests this rootstock may have better consistency in tolerance to HLB than other rootstocks. It has been shown that nucellar seedlings of 'US-942' have few symptoms of HLB following Las infection (Albrecht and Bowman, 2012), are slower to have detectable Las following inoculation (Bowman and Albrecht, 2015), and infected plants have a dramatically lower Las titer in the roots than does sweet orange (Hall et al., 2016). Although suggestive, it is uncertain whether this reduced symptomology and bacterial titer in the seedlings is directly associated with the improved HLB tolerance of sweet orange trees grafted on 'US-942' in the field.

One impact of HLB disease on the Florida citrus industry has been to dramatically complicate the assessment of rootstock suitability for individual commercial plantings. Some rootstocks that were previously outstanding for commercial use, have exhibited exceptional sensitivity to HLB in some commercial sites, while other new rootstocks have appeared to be superior to use under those conditions (Bowman and McCollum, 2015). A recent University of Florida Extension publication provides a summary of information on the traits of 45 different citrus rootstocks that are commercially used or available in Florida (Castle et al., 2015a). In many cases, information about important traits of rootstocks is lacking or anecdotal, and assessment of rootstock tolerance to HLB remains a controversial issue (Castle et al., 2015b). Nevertheless, growers wanting to plant new citrus trees must choose a rootstock, and they make their choices based on the best information available.

Since the release of 'US-812' in 2001, and subsequent release of 'US-802', 'US-897', and 'US-942', commercial use of these four USDA rootstocks in Florida has steadily grown, until in 2015 they, in combination, were used for more propagations than any other single rootstock. Assessment of grower interest suggests that these four selections continue to be among the most desired new rootstocks (Giles and Rusnak, 2015). Establishment of many additional seed source trees, substantial work to develop micropropagation systems for these rootstocks, and the indication of generally good nursery performance for these rootstocks, bode well for the nursery industry to supply plants for the continued expansion in use of the four USDA rootstocks. Results from field trials, including those heavily affected by HLB, indicate that relative performance of 'US-942' and 'US802 ' rootstocks, in particular, continues to appear outstanding in comparison with other commercial Florida rootstocks for some locations. Commercial interest in 'US-812' remains strong because of a very positive experience by many growers using this rootstock over the past 15 years. Interest in 'US897' remains especially strong because of the dwarfing effect of this rootstock and consequent suitability for high density plantings and intensive tree management. Many Florida growers have interpreted the results of field trials comparing rootstock performance as demonstration that the use of the right rootstock is a key component of the solution to the HLB problem.

\section{Literature Cited}

Albrecht, U. and K.D. Bowman. 2011. Tolerance of the trifoliate citrus hybrid US-897 (Citrus reticulata Blanco x Poncirus trifoliata L. Raf.) to Huanglongbing. HortScience 46:16-22.

Albrecht, U. and K.D. Bowman. 2012. Tolerance of trifoliate citrus rootstock hybrids to Candidatus Liberibacter asiaticus. Sci. Hort. 147:71-80.

Albrecht, U., G. McCollum, and K.D. Bowman. 2012. Influence of rootstock variety on Huanglongbing disease development in field-grown sweet orange (Citrus sinensis [L.] Osbeck) trees. Sci. Hort. 138:210-220.

Blumer, S. and J. Pompeu, Jr. 2005. Performance of citrandarins and other trifoliate hybrid rootstocks in Sao Paulo, Brazil. Revista Brasileira de Fruticultura. Jaboticabal 27(2):264-267.

Bowman, K.D. 1998. Performance of 'Fallglo' on ten rootstocks in Lake County. Proc. Fla. State Hort. Soc. 111:177-180.

Bowman, K.D. 2001. Notice to fruit growers and nurserymen relative to the naming and release of the US-812 citrus rootstock. U.S. Department of Agriculture, ARS, Washington, DC.

Bowman, K.D. 2007a. Notice to fruit growers and nurserymen relative to the naming and release of the US-802 citrus rootstock. U.S. Department of Agriculture, ARS, Washington, DC.

Bowman, K.D. 2007b. Notice to fruit growers and nurserymen relative to the naming and release of the US-897 citrus rootstock. U.S. Department of Agriculture, ARS, Washington, DC.

Bowman, K.D. and U. Albrecht. 2015. Comparison of gene expression changes in susceptible, tolerant, and resistant hosts in response to infection with Citrus tristeza virus and huanglongbing. J Cit Pathol. iocv_journalcitruspathology_30450.

Bowman, K.D. and S.M. Garnsey. 2001. A comparison of five sour orange rootstocks and their response to Citrus tristeza virus. Proc. Fla. State Hort. Soc. 114:73-77.

Bowman, K.D., J.H. Graham, and R.C. Adair, Jr. 2003. Young tree growth in a flatwoods rootstock trial with Diaprepes weevil and Phytophthora diseases. Proc. Fla. State Hort. Soc. 116:249-251.

Bowman, K.D., R.D. Hartman, A.E. Lamb, and H.K. Wutscher. 1997. Enhancing development of improved rootstocks by tissue culture propagation and field performance of selected rootstocks. Proc. Fla. State Hort. Soc. 110:10-13.

Bowman, K.D. and G. McCollum. 2010. Notice to fruit growers and nurserymen relative to the naming and release of the US-942 citrus rootstock. U.S. Department of Agriculture, ARS, Washington, DC.
Bowman, K.D. and G. McCollum. 2015. Five new citrus rootstocks with improved tolerance to huanglongbing. HortScience 50:1731-1734.

Bowman, K.D., G. McCollum, and U. Albrecht. 2016. Performance of 'Valencia' orange (Citrus sinensis [L.] Osbeck) on 17 rootstocks in a trial severely affected by huanglongbing. Sci. Hort. 201:355-361.

Bowman, K.D. and F.M. Roman. 1999. New rootstocks for orange and mandarin. Proceedings of the Caribbean Food Crops Society. 35:119-130.

Bowman, K.D. and R.E. Rouse. 2006. US-812 Citrus Rootstock. HortScience 41:832-836.

Castle, W.S., K.D. Bowman, J.C. Baldwin, J.W. Grosser, and F.G. Gmitter, Jr. 2011. Rootstocks affect tree growth, yield, and juice quality of 'Marsh' grapefruit. HortScience 46:841-848.

Castle, W.S., K.D. Bowman, J.W. Grosser, S.H. Futch, and J.H. Graham. 2015a. Florida citrus rootstock selection guide. 3rd ed. University of Florida IFAS Extension Publication SP-248.

Castle, W.S., J.W. Grosser, K.D. Bowman, and E. Stover. 2015b. An HLB-tolerant citrus rootstock: What exactly does that mean? p. 16-19. Citrus industry Magazine, June 2015.

Castle, W.S., R.J. Schnell, J.H. Crane, J.W. Grosser, F.G. Gmitter, S.T. Ayala, and K.D. Bowman. 2004. Evaluation of new citrus rootstocks for 'Tahiti' lime production in southern Florida. Proc. Fla. State Hort. Soc. 117:174-181.

Derrick, K.S. and L.W. Timmer. 2000. Citrus blight and other diseases of recalcitrant etiology. Annu. Rev. Phytopathol. 38:181-205.

Folimonova, S.Y., C.J. Robertson, S.M. Garnsey, S. Gowda, and W.O. Dawson. 2009. Examination of the responses of different genotypes of citrus to huanglongbing (citrus greening) under different conditions. Phytopathology 99:1346-1354.

Giles, F. and P. Rusnak. 2015. Growers seeking solutions. Florida Grower Magazine. Citrus Annual Mid-Dec. 2015:16-18.

Hall, D.G., U. Albrecht, and K.D. Bowman. 2016. Transmission Rates of 'Ca. Liberibacter asiaticus' by Asian Citrus Psyllid Are Enhanced by the Presence and Developmental Stage of Citrus Flush. J. Econ. Entomol. 109:558-563.

Kesinger, M. 2015. Bureau of citrus budwood registration, annual report 2014-15. Florida Department of Agriculture and Consumer Services, Winter Haven, FL.

McCollum, T.G., K.D. Bowman, and W.S. Castle. 2002. Effects of rootstock on fruit quality and postharvest behavior of 'Marsh' grapefruit. Proc. Fla. State Hort. Soc. 115:44-46.

Pompeu, J., Jr., F.F. Laranjeira, and S. Blumer. 2002. 'Valencia' sweet orange trees grafted on trifoliate hybrids. Scientia Agricola, Piracicaba 59:93-97.

Pompeu, J., Jr., and S. Blumer. 2014. Trifoliate hybrids as rootstocks for Pêra sweet orange tree. Pesquisa Agropecuária Tropical, Goiania 44(1):9-14.

Ritenour, M.A., D. Huating, K.D. Bowman, B.J. Boman, E. Stover, and W.S. Castle. 2004. Effect of rootstock on stem-end rind breakdown and decay of fresh citrus. HortTechnology 14:315-319.

Wutscher, H.K. and K.D. Bowman. 1999. Performance of 'Valencia' orange on 21 rootstocks. HortScience 34:622-624.

Wutscher, H.K., M. Cohen, and R.H. Young. 1977. Zinc and water-soluble phenolic levels in the wood for the diagnosis of citrus blight. Plant Dis. Reptr. 61(7):572-576.

Wutscher, H.K. and L.L. Hill. 1995. Performance of 'Hamlin' orange on 16 rootstocks in Eastcentral Florida. HortScience 30:41-43. 